\title{
Development and Evaluation of a Multiplex PCR for Simultaneous Detection of Five Foodborne Pathogens
}

\author{
Thuy Trang Nguyen ${ }^{1,3 \#}$, Vo Van Giau ${ }^{2,3 \# *}$, Tuong Kha Vo ${ }^{4 *}$ \\ ${ }^{1}$ Department of Pharmacy, Ho Chi Minh City University of Technology (HUTECH), Ho Chi Minh City, Vietnam \\ ${ }^{2}$ Deparment of Faculty of Food Technology, Ho Chi Minh City University of Food Industry (HUFI), 140 Le Trong Tan, Tan Phu district, Ho Chi Minh City, \\ Vietnam \\ ${ }^{3}$ Department of Bionano Technology, Gachon Medical Research Institute, Gachon University, Seongnam, South Korea \\ ${ }^{4}$ Vietnam Sports Hospital, Ministry of Culture, Sports and Tourism, Do Xuan Hop Road, My Dinh I Ward, Nam Tu Liem District, Hanoi City, Vietnam \\ ${ }^{\#}$ Authors contributed equally to this article
}

Received: 01 December, 2016; Accepted: 16 December, 2016; Published: 26 December, 2016

*Corresponding author: Vo Van Giau, Deparment of Faculty of Food Technology, Ho Chi Minh City University of Food Industry, 140 Le Trong Tan, Tan Phu district, Ho Chi Minh City, Vietnam, Tel: (+84) 83-816-1673 (ex 108); Fax: (+84) 83-816-1673; E-mail: vovangiau911@gmail.com

\begin{abstract}
Foodborne pathogens present serious concerns to human health and can even lead to fatalities. The gold standard for pathogen identification - bacterial culture - is costly and time consuming. A cheaper and quicker alternative will benefit in controlling food safety. In this study, we developed a multiplex-PCR protocol for simultaneous detection of five Foodborne pathogens including Escherichia coli 0157:H7, Staphylococcus aureus, Salmonella spp., Listeria monocytogenes, and Vibrio cholerae, based on five genes stx1, femA, invA, iap, và $c t x A$, respectively. Specific primers for multiplex PCR amplification of the stx (Shiga-like toxin), nuc (thermo nuclease), inv $A$ (invasion protein A), iap (invasive associative protein), and ctx $A$ (cholera toxin A) genes that were established to amplify simultaneous detection of the target pathogens. The assay was also validated for its specificity, sensitivity, and applied to test some spiked food samples. The results showed the products expected multiplex PCR fragments of approximately 112, 244, 301, 453, 518 and $720 \mathrm{bp}$ for $S$. aureus, Salmonella spp. V. cholera, L. monocytogenes, E. coli $0157: \mathrm{H} 7$ and $16 \mathrm{~S}$ rRNA, respectively. The assay was specific to the targeted pathogens and was sufficiently sensitive and robust to effectively analyze market samples. The whole process took less than $24 \mathrm{~h}$ to complete indicating that the assay is suitable for reliable and rapid identification of these five foodborne pathogens, which could be suitable in microbial epidemiology investigation.
\end{abstract}

Keywords: Foodborne pathogens; Multiplex-PCR; Five genes; Detection; Simultaneous

\section{Introduction}

The incidence of foodborne diseases has increased over the years and is a serious health hazard in both developing and developed countries. Escherichia coli 0157:H7 (E. coli 0157:H7), Salmonella spp., and Vibrio cholera (V. cholera) are likely the most common cause of foodborne disease $[1,2]$. The well-known $E$. coli bacteria that produce Shiga toxin (STEC) is E. coli 0157:H7 strains are foodborne infectious agents that cause a number of life-threatening diseases, including hemorrhagic colitis (HC) and hemolytic uremic syndrome (HUS) [3]. According to recent reports by the Center for Disease Control and Prevention from 2011-2014, there were 11 multistate outbreaks of STEC in the United States of America with six of them attributed to E. coli 0157:H7. With low infectious dose, an inoculation of fewer than 10-100 CFU of E. coli 0157:H7, is sufficient to cause infection [4]. Shiga toxin (Stx) is one of the major virulence factors involved in E. coli 0157:H7 pathogenesis [5]. The stx gene is well associated with a prophage and including a variety of subtypes shiga toxin that are described as stx1, stx1c, stxfc, stx2, stx2e, stx2d and stx2g [6]. With capable of producing enterotoxins and coagulase enzyme, Staphylococcus aureus (S. aureus) has already been involved in a number of food-poisoning outbreaks. Producing of an extracellular thermostable nuclease and coagulase with the same frequencies that were important phenotypic identifying markers of $S$. aureus [7-9]. The nuc gene encodes for the production of a thermostable endonuclease enzyme, which has been used for the correct identification of $S$. aureus in previous studies $[10,11]$. Approximately 20,000 hospitalizations and 378 deaths per year in the United States, Salmonella spp. are the leading bacterial cause of acute gastrointestinal illness. There are some serotypes as $S$. enteritidis, $S$. typhi, S. paratyphi A, $S$. paratyphiB, $S$. paratyphiC, and $S$. choleraesuis that can cause foodborne illnesses $[12,13]$. The invA gene is a good candidate gene to invade mammalian cells and subsequently cause disease $[14,15]$, and it presents in all pathogenic serovars as a maker has been the most frequently used for Salmonella spp. Detection [16-18]. Listeria monocytogenes (L. monocytogenes) has been found from dairy, frozen aquatic and meat products $[19,20]$ and is associated with listeriosisis, a servere disease with morbidity and of high mortality of 20-30\% [21-23]. One of the main virulence genes, the iap gene encodes p60 protein, is associated with the presence of the invasion-associated as the mechanism of pathogenicity in L. monocytogenes. Similarity, cholera has been one of the most feared diseases for human. The vast majority of strains associated with epidemic cholera are attributed to toxigenic Vibrio cholera ( $V$. cholerae) with the 01 serotype [24]. The ctxAB operon that encodes cholera toxin 
resides in filamentous bacteriophage СТХ $\Phi$ genome confer the ctx operon to $V$. cholerae strains as a prophage that carries the $\operatorname{ctx} A$ and $\operatorname{ctx} B$ genes.

Illnesses resulting from the consumption of foods contaminated with pathogens and/ or their toxins have a wide range of economic and public health impact worldwide [25]. The current gold-standard method for detecting foodborne pathogen in food encompasses enrichment with subsequent plating on selective media, biochemical reactions, and serological tests, which are time-consuming and labor-intensive [26]. Currently, the official procedure for detection of pathogenic bacteria also used to a cultural method, and this procedure could take from 3 to 5 days for confirmation, which is a disadvantage when the results are needed promptly $[27,28]$. Hence, faster technologies have been applied to develop rapid and enhance sensitive analytical protocol for the foodborne pathogens. The polymerase chain reaction (PCR) is still the most commonly used for detection of the targets bacterial, which based on the identification of the target gene of specific bacteria present after the exponential application with the high sensitivity and specificity. It has become an important tool for detecting and identifying pathogenic organisms in various foods [2933]. Consequently, since multiplex PCR assay has been able to simultaneously amplify multiple gene targets by using several sets of target specific or degenerated primers in a single tube [34], it has greatly improved the sensitivity, specificity, and speed of detecting pathogenic organisms [35]. Furthermore, multiplex PCR assay, in comparison with uniplex PCR assays, could save considerable time and workload, and improve efficiency [26,30,31-36].

In this study, we developed a multiplex PCR assay for the rapid and simultaneous detection of five epidemic foodborne pathogens, namely Escherichia coli 0157:H7, Staphylococcus aureus, Salmonella spp, Listeria monocytogenes, and Vibrio cholera. The performance of the multiplex assay, including its sensitivity, specificity, and precision in quantitative analyses, was comprehensively evaluated in comparison with the traditional methods. The capacity of the proposed assay to detect multiple target pathogens simultaneously was also tested, and the effect of non-target interference on the assay performance was evaluated. The results obtained with artificially contaminated food samples and real samples demonstrate that the multiplex PCR assay can simultaneously detect these five target foodborne pathogens in foods with high sensitivity and reliability.

\section{Materials and Methods}

\section{Bacterial strains and their cultivation}

The strains used for specificity testing are listed in Table 1. For the identification of five food-borne pathogens and the sensitivity of the multiplex PCR assay experiments, the following strains were used: three strains E. coli 0157:H7, one produces both Stx1 and Stx2 (NLU), and one produces Stx1 only (NIHE), the last one has Stx2 only (HCMUS), all were obtained from previously worked [37,38], S. aureus ATCC6538, S. enterica ATCC 14028,
L. monocytogenes A TCC15313, and V. cholera ATCC 17802. All strains were grown in tryptic soy broth (TSB) or brain heart infusion (Merck, Germany) at $37^{\circ} \mathrm{C}$ for $24 \mathrm{~h}$. The simultaneous enrichment broth (SEB), which used for simultaneous enrichment of five pathogenic bacteria in this study, was described previously by Kobayashi et al. [39].Then, the culture broth was used for DNA extraction and subjected to the multiplex PCR assay.

\section{Pathogen detection by the conventional culture method}

For detection of E. coli 0157:H7, each $25 \mathrm{~g}$ of each sample was diluted in $225 \mathrm{~mL}$ of Modified Tryptone Soya broth (mTSBOxoid, UK) added with Novobiocin, homogenized for 2 min at $260 \mathrm{rpm}$ using a Stomacher (Model 400 circulator, Seward, Norfolk, England) and incubated for $18-24 \mathrm{~h}$ at $41.5^{\circ} \mathrm{C}$ according to ISO 16654 (2001) method, as well as the remaining steps. After enrichment and immune magnetic concentration steps, the selective and differential isolation of enterohemorrhagic $E$. coli 0157:H7 was carried out on MacConkey Agar with Sorbitol, Cefixime, and Tellurite (CT-SMAC-Oxoid, UK) and incubated overnight at $42^{\circ} \mathrm{C}$. From each sample one well isolated suspected colony was transferred to tryptone soy agar (Oxoid) and incubated for $24 \mathrm{~h}$ at $37^{\circ} \mathrm{C}$. Subsequently, one isolate from the subculture was further tested for agglutination with an $E$. coli

Table1. Bacterial strains and their sources were employed in this study

\begin{tabular}{|c|c|c|c|}
\hline No & Bacteria & Serovar & Source \\
\hline \multicolumn{4}{|c|}{ The target strains } \\
\hline 1 & E. coli & 0157:H7 & NIHE \\
\hline 2 & E. coli & 0157:H7 & HCMUS \\
\hline 3 & E. coli & 0157:H7 & NLU \\
\hline 4 & S. aureus & & ATCC6538 \\
\hline 5 & Salmonella enterica & & ATCC14028 \\
\hline 6 & L. monocytogenes & & ATCC15313 \\
\hline 7 & V. cholerae & & ATCC17802 \\
\hline \multicolumn{4}{|c|}{ The non-target strains } \\
\hline 1 & E. coli & & ATCC 11775 \\
\hline 2 & E. coli & & ATCC 25922 \\
\hline 3 & E. coli(I1) & & $\begin{array}{l}\text { Clinical } \\
\text { isolate }\end{array}$ \\
\hline 4 & E. coli(I2) & & $\begin{array}{l}\text { Clinical } \\
\text { isolate }\end{array}$ \\
\hline 5 & E. coli(I3) & & $\begin{array}{l}\text { Chicken } \\
\text { isolate }\end{array}$ \\
\hline 6 & E. $\operatorname{coli}(\mathrm{I} 4)$ & & Beef isolate \\
\hline 7 & E. coli(I5) & & Salad isolate \\
\hline 8 & $\begin{array}{l}\text { Clostridium } \\
\text { perfringens }\end{array}$ & & ATCC13124 \\
\hline 9 & Bacillus cereus & & ATCC11778 \\
\hline 10 & Shigella sonnei & & ATCC 9290 \\
\hline
\end{tabular}

ATCC: American Type Culture Collection;

NIHE: National Institute Of Hygiene And Epidemiology;

HCMUS: HCM University of Science; NLU: Nong Lam University 
0157:H7 latex test kit (Becton-Dickinson, USA) for sero group 0157:H7 confirmation. For detection of $S$. aureus, each $10 \mathrm{~g}$ food sample was diluted with $90 \mathrm{~mL}$ of sterile Saline Petone Water (Merck, Germany) and pummeled in a Stomacher apparatus for 1 minute; One milliliter of the culture was added to $10 \mathrm{~mL}$ of Giolitti-Cantoni broth (Merck, Germany) and incubated at $37^{\circ} \mathrm{C}$ for 48 hours. One loop full of the culture with black color was then streaked onto Baird Paker Agar (Merck, Germany) and incubated at $37^{\circ} \mathrm{C}$ for 48 hours. The resulting presumptive $S$. aureus colonies were tested to biochemical screening using a coagulase test. For detection of Salmonella spp. Each 25g food sample was diluted with $225 \mathrm{~mL}$ of sterile Buffered Peptone Water (Merck, Germany) and pummeled in a Stomacher apparatus for 2 minutes; the mixture was then incubated for 18 hours at $37^{\circ} \mathrm{C}$. One milliliter of the culture was added to $10 \mathrm{~mL}$ of Rappaport-Vassiliadis soy peptone broth (Merck, Germany) and incubated at $42,5^{\circ} \mathrm{C}$ for 18 hours. One loop full of the culture was then streaked onto Xylose lysine desoxycholate agar (Merck, Germany) and incubated at $37^{\circ} \mathrm{C}$ for 24 hours. The resulting presumptive Salmonella colonies were tested to biochemical screening and serological confirmation using Salmonella polyvalent 0, 01 antisera (BectonDickinson, USA). For detection of L. monocytogenes, $25 \mathrm{~g}$ of the food samples were mixed with $225 \mathrm{~mL}$ of sterile Fraser Broth Listeria enrichment broth (Merck, Germany) and pummeled in a Stomacher for 1 minute, followed by incubation for 48 hours at $30^{\circ} \mathrm{C}$. One loopful of the culture broth was streaked onto Chromogenic Listeria agar with selective supplement (Oxoid, Hampshire, UK) and incubated at $37^{\circ} \mathrm{C}$ for 48 hours. Presumptive colonies were streaked onto horse blood agar and TSA plates and incubated at $35^{\circ} \mathrm{C}$ for 48 hours. The resulting presumptive Listeria colonies were submitted for biochemical screening (oxidase test, catalase test, and Gram staining). For detection of $V$. cholera, the composited sample of $25 \mathrm{~g}$ and to added $225 \mathrm{ml}$ of enrichment medium alkaline saline peptone water (Merck, Germany)and pummeled in a Stomacher for 1 minute, followed by incubation for 24 hours at $41.5^{\circ} \mathrm{C}$. One loopful of the culture was then streaked onto Thiosulfate Citrate Bile and Sucrose agar (Merck, Germany) and incubated at $37^{\circ} \mathrm{C}$ for 24 hours. The resulting presumptive $V$. cholerae colonies were submitted for biochemical screening and serological confirmation.

\section{DNA isolation}

DNA extraction was performed by boiling $1 \mathrm{ml}$ of each overnight culture pre-enrichment samples or culture in all the strains was boiled for $10 \mathrm{~min}$ in an Isotemp heat block (Fisher Scientific, Pittsburgh, PA) and centrifuged at $12,000 \times \mathrm{g}$ for $2 \mathrm{~min}$. The supernatants were saved for posterior use as DNA template for all PCR reactions at $-20^{\circ} \mathrm{C}$.

\section{Oligonucleotides primers and multiplex PCR assays}

The oligonucleotide primers used in this study are shown in Table 2. For multiplex PCR analysis, two primers pairs were used: stx, which is specific primers to various stx 1 and stx 2 gene for E. coli0157:H7described by Yamasaki S, et al (1996) [28]; the primer inv A, specific for Salmonella spp. described by designed by Chiu et al [40]; the primer iap, specific for L. monocytogenes described by designed by Manzan et al [41]; and the primer ctxA, specific for $V$. cholera described by designed by Shirai et al [42]. The rest of target-specific primers in this work were designed to amplify for the nucgene of S.aureus and 16S rRNA gene sequence of bacterial with a amplification product of 112 bp and $720 \mathrm{bp}$, respectively. The primers were selected from a complete sequence from S. aureus strain DQ399678 and 16S rRNA gene sequences for most bacteria and archaea are available on public databases from the Gen Bank database. Primers were designed using the software Fast PCR [43]. The specificity of pair of primers was evaluated by nucleotide similarity searched with the BLAST algorithm at the NCBI website (http: www.ncbi.nlm. nih.gov). Additionally, the PCR amplification was evaluated with DNA samples from the bacterial species listed in Table 2.

The 16S rRNA gene was also targeted as an internal control of the presence of amplifiable bacterial DNA. The single PCR was performed a total volume of $50 \mu \mathrm{l}$ using the Veriti96-Well Thermal Cycler (Applied Biosystems, Foster City, CA)in reaction mixtures (Promega) containing $0.5 \mu \mathrm{M}$ each primer, $200 \mu \mathrm{M}$ each dNTP, $3 \mathrm{mM} \mathrm{MgCl}_{2}$, $1.5 \mathrm{U}$ Taq DNA polymerase, $1 \mathrm{x}$ PCR

Table2. Primer pairs and its characteristics employed for the multiplex PCR

\begin{tabular}{|c|c|c|c|c|c|}
\hline Organisms & $\begin{array}{l}\text { Forward primers } \\
\left(5^{\prime}-3^{\prime}\right)\end{array}$ & $\begin{array}{l}\text { Reverse primer } \\
\left(5^{\prime}-3^{\prime}\right)\end{array}$ & $\begin{array}{l}\text { Target gene / } \\
\text { primer }\end{array}$ & $\begin{array}{l}\text { Amplicon } \\
\text { size (bp) }\end{array}$ & Reference \\
\hline Staphylococcus aureus & AATTACATAAAGAACCTGCGACT & GCACTTGCTTCAGGACCATATT & nuс & 112 & This study \\
\hline $\begin{array}{l}\text { Escherichia coli } \\
\text { 0157:H7 }\end{array}$ & GAGCGAAATAATTTATATGTG & TGATGATGGCAATTCAGTAT & stx & 518 & {$[28]$} \\
\hline Salmonella spp. & ACAGTGCTCGTTTACGACCTGAAT & AGACGACTGGTACTGATCGATAAT & $\operatorname{inv} A$ & 244 & {$[40]$} \\
\hline $\begin{array}{l}\text { Listeria } \\
\text { monocytogenes }\end{array}$ & GGGCTTTATCCATAAAATA & TTGGAAGAACCTTGATTA & iap & 453 & {$[41]$} \\
\hline Vibrio cholerae & CTCAGACGGGATTTGTTAGGCACG & TCTATCTCTGTAGCCCCTATTACG & $\operatorname{ctx} A$ & 301 & [42] \\
\hline Bacterial DNA & AGAGTTTGATCATGG CTCAGG & GGACTACCAGGGTATCTAATT & 16S rRNA & 720 & This study \\
\hline
\end{tabular}


buffer and $2 \mathrm{l}$ template. A negative control containing the same reaction mixture except the DNA template was included in every experiment. While the multiplex PCR conditions were the same as the single PCR assay except for the concentration of primers and incorporated Betaine into each reaction. The optimized concentrations of the six primer pairs in the multiplex were $0.135 \mu \mathrm{M}$ for $s t x \mathrm{~F} / \mathrm{R}$; $1 \mu \mathrm{M}$ for nuc-F/ $\mathrm{R} ; 1.2 \mu \mathrm{M}$ for $i n v A-\mathrm{F} / \mathrm{R}$; $1.65 \mu \mathrm{M}$ iap-F/ $\mathrm{R}$; $0.125 \mu \mathrm{M}$ for ctxA-F/ $\mathrm{R}$, and $0.8 \mu \mathrm{M}$ for $16 \mathrm{~S}$ -F/ R. Since PCR additives, such as dimethyl sulfoxide, glycerol, bovine serum albumin, or betaine, have been reported to be of benefit in multiplex PCR. The aim is to enhance amplification, adding with $2.5 \mathrm{M}$ concentrations of Betaine were incorporated in all multiplex method.

The PCR program was carried out at $95^{\circ} \mathrm{C}$ for $5 \mathrm{~min}$, followed denaturing by 35 cycles of $94^{\circ} \mathrm{C}$ for $1 \mathrm{~min}, 57.5^{\circ} \mathrm{C}$ for $1 \mathrm{~min}$, and $72^{\circ} \mathrm{C}$ for $1 \mathrm{~min}$, and a final $5 \mathrm{~min}$ of $72^{\circ} \mathrm{C}$ for extension. PCR products were electrophoresed in $1 \%$ agarose at $100 \mathrm{~V}$ for $50 \mathrm{~min}$ followed by staining with ethidium bromide $(0.5 \mathrm{~g} / \mathrm{mL})$ then visualized under ultraviolet light, and the results were recorded by photography using an ultraviolet trans illuminator (Gel Doc XR system, Bio-Rad).

\section{Specificity of the multiplex PCR assay}

To assess the specificity of the multiplex PCR assay, cultures of 7 target pathogens and 10 non-target bacterial strains (Table 1) were prepared.The purity of the genomic DNA was assessed by determining the A260/ A280 ratio using a spectrophotometer(BioMate 3; Thermo spectronic, Rochester, NY). The multiplex PCR was performed individually for each of DNA samples of 17 strains in multiplex primer system using the experimental conditions described above. The inclusivity and exclusivity were calculated according to the MicroVal protocol [44]. Inclusivity is the ability of the PCR method to detect the target analyze from a wide range of strains. Inclusivity is defined as the percentage of target DNA samples that gave a correct positive signal. Exclusivity is defined as the percentage of nontarget DNA samples that gave a correct negative signal.

\section{Multiplex PCR evaluation in spiked food samples}

In order to validate the multiplex PCR assay in food, the three Vietnam of food samples matrices including vegetables, seafood products and raw meat fork that were purchased from a local super market and were immediately transported in insulated coolers at $4^{\circ} \mathrm{C}$ to the laboratory for inoculation and analysis on the same day. Before inoculating experiments, the food samples were carefully tested for the presence of E. coli 0157:H7, S. aureus, Salmonella spp. L. monocytogenes, and V. cholera using the conventional culture method as described above for each of once. Make sure none of these pathogens could be detected by culture in these food samples. The five food borne pathogens were cultured in TSB at $37^{\circ} \mathrm{C}$ for $18 \mathrm{~h}$ prior to decimal dilution in a sterile saline solution $(0.85 \% \mathrm{NaCl})$ in order to obtain levels of inoculation (colony-forming units $[\mathrm{CFU}] / \mathrm{g}$ ). One $\mathrm{mL}$ in each dilution was spread on TSB agar to determine bacterial counts and the equal concentration also used to prepare bacterium representing to spiked $25 \mathrm{~g}$ food samples. Each $25 \mathrm{~g}$ food samples were inoculated with $1 \mathrm{~mL}$ of each level of inoculation, and then placed with $225 \mathrm{~mL}$ of sterile SEB medium. A nature sample with non-inoculated was employed as a negative control. The mixture was homogenized in a Stomacher apparatus for 1 minute. After each 12-h, 18-h and 24-hincubation times, a $1 \mathrm{~mL}$ aliquot was collected from each sample in each period of time incubation and DNA was extracted as described.

\section{Results and Discussion}

\section{Identification of food-borne pathogens}

Rapid and simultaneous detection of multiple pathogenic bacteria in foods is of great importance to ensure food safety. In this study, we developed and evaluated a multiplex PCR for simultaneous detection of the five food borne pathogens including E. coli 0157:H7, S. aureus, Salmonella spp, L. monocytogenes and $V$. cholera in a single reaction. In order to ensure specificity and sensitivity and toavoid cross-reactions, primer pair selection is critical in the multiplex PCR assay for the simultaneous detection of five foodborne pathogens. All six of primers (and one is $16 \mathrm{~S}$ rRNA) that were erected, designed and analysed for the simultaneous detection of five food borne pathogens using the online available software as described by Kalendar et al. [43]. The table 2 shows all information of the primer 16S-F/ R for amplification of a 720-bp sequence from the 16S rRNA gene of bacterial DNA, stx-F/ R for amplification of a 518-bp sequence from the stx gene of E. coli 0157:H7,iap-F/ R for amplification of a 453-bp sequence from the iap gene of L. monocytogenes, ctxA-F/ Rfor amplification of a 301-bp sequence from the $c t x A$ geneof $V$. cholerae, inv-F/ R for amplification of a 244-bp sequence from the invA gene of Salmonella spp., and nuc-F/ R for amplification of a 112-bpsequence from the nuc gene of S. aureus. Furthermore, successful multiplexing of multiplex PCR assay requires careful experimental design and optimization of reaction conditions. To achieve accurate template quantification in a multiplex PCR assay, each reaction must efficiently amplify a single product, and amplification efficiency must be independent of template concentration and the amplification of other templates. The annealing temperature of a multiplex PCR assay is one of the most critical parameters for reaction specificity. We tested a range of temperatures above and below the calculated Tm of the primers. Fortunately, based on the yield of PCR products for the seven target genes, the results showed an optimal multiplex annealing temperature of $59,5^{\circ} \mathrm{C}$. As can be seen, the results showed that these six primer pairs in the multiplex PCR assay worked well independently, and could distinguish the five pathogens from each other with high specificity, and PCR amplification was obtained the size of the PCR product followed by identification in terms of the expected size. Five food-borne pathogens, including E. coli 0157:H7 (NLU), S. aureus ATCC6538, S. enterica ATCC 14028, L. monocytogenes ATCC15313, and V. Cholera TCC 17802were detected simultaneously through the multiplex PCR assay using multiplex primer set and the conditions as described above. As the Table 3 and Fig. 1 show the multiplex PCR assay was successfully developed to simultaneously identify the five 
foodborne pathogens based on the generation of the expected PCR fragments of $112 \mathrm{bp}, 244 \mathrm{bp}, 301 \mathrm{bp}, 453 \mathrm{bp}$ and $518 \mathrm{bp}$ for S. aureus ATCC6538, Salmonella enterica ATCC 14028, V. cholera ATCC 17802, L. monocytogenes ATCC15313and E. coli 0157: H7(NLU), respectively. In addition, no PCR product corresponding with target microorganism was detected in negative control using the multiplex primer. In addition, PCR products corresponding with the positive-control $16 \mathrm{~S}$ rRNA gene $(720 \mathrm{bp})$ were detected from pure cultures of seven pathogens.

\section{Specificity of the multiplex PCR Assay}

The specificity of the multiplex PCR conducted with the seven target strains and 10 non-target bacterial strains. All three E. coli 0157:H7 strains E. coli 0157:H7(NIHE), E. coli 0157:H7(HCMUS), E. coli 0157:H7(NLU), S. aureus ATCC6538, S. enterica ATCC 14028, L. monocytogenes ATCC15313, and V. cholera ATCC 17802 strains were positive in the multiplex PCR assay and all non-target bacterial including E. coli ATCC 11775, E. coli ATCC 25922, E. coli(I1), E. coli(I2), E. coli(I3), E. coli(I4), E. coli (I5), C. perfringens ATCC13124, B. cereusATCC11778 and S. sonnei ATCC 9290were negative in the assay, whereas 16S rRNA was amplified as expected. No mispriming or non-specific amplification was observed. Expectedly, the size of each pathogen amplicon was obtained only from the target foodborne pathogens, resulted in $100 \%$ inclusivity and $100 \%$ exclusivity. Even of target food borne pathogens and ten non-target pathogens were used to evaluate and verify the specificity of primers in this study, each primer pair by the multiplex PCR on DNA templates (Table 4). These results demonstrated that our multiplex PCR assay could be used to identify each of these five foodborne pathogens.

\section{Evaluation of the multiplex PCR assay with spiked food samples}

In order to assess the detection sensitivity of the multiplex PCR assay for its application to food samples, three of kind of food samples (vegetables, seafood products and raw meat fork) inoculated with E. coli 0157:H7(NLU), S. aureus ATCC6538, S. enterica ATCC 14028, L. monocytogenes ATCC15313, and V. cholera ATCC 17802 with seven level of the number of viable cells $\left(0,10^{0}, 10^{1}, 10^{2}, 10^{3}, 10^{4}\right.$ and $\left.10^{5} \mathrm{CFU} / \mathrm{ml}\right)$ were employed and a

Table 3. Evaluation of the specificity of all PCR primers using various pathogenic bacterial

\begin{tabular}{|c|c|c|c|c|c|c|c|}
\hline \multirow[b]{2}{*}{ Strain } & \multirow[b]{2}{*}{ Source } & \multicolumn{6}{|c|}{ Genes/ Primers } \\
\hline & & stx & nuc & $\operatorname{invA}$ & iap & $\operatorname{ctx} A$ & $\begin{array}{c}16 \mathrm{~S} \\
\text { rRNA }\end{array}$ \\
\hline E. coli $0157: \mathrm{H} 7$ & NIHE & + & - & - & - & - & + \\
\hline E. coli 0157:H7 & HCMUS & + & - & - & - & - & + \\
\hline E. coli 0157:H7 & NLU & + & - & - & - & - & + \\
\hline S. aureus & ATCC6538 & - & + & - & - & - & + \\
\hline Salmonella spp. & ATCC14028 & - & - & + & - & - & + \\
\hline L. monocytogenes & ATCC15313 & - & - & - & + & - & + \\
\hline V. cholerae & ATCC17802 & - & - & - & - & + & + \\
\hline
\end{tabular}

Table 4. Specificity test for the multiplex PCR assay; a minus (-) indicates the absence of a band and a plus (+) indicates the presence of a band

\begin{tabular}{|c|c|c|c|c|c|c|}
\hline \multirow{2}{*}{ Species } & \multicolumn{6}{|c|}{ Genes } \\
\hline & nuc & invA. & $\operatorname{ctx} A$ & iap & stx & 16S rRNA \\
\hline E. coli $0157: \mathrm{H7}$ (NIHE) & - & - & - & - & + & + \\
\hline E. coli $0157: \mathrm{H7}$ (HCMUS) & - & - & - & - & + & + \\
\hline E. coli $0157: \mathrm{H7}(\mathrm{NLU})$ & - & - & - & - & + & + \\
\hline S. aureusATCC6538 & + & - & - & - & - & + \\
\hline $\begin{array}{l}\text { Salmonella } \\
\text { entericaATCC14028 }\end{array}$ & - & + & - & - & - & + \\
\hline L.monocytogenesATCC15313 & & - & - & + & - & + \\
\hline V. choleraATCC17802 & - & - & + & - & - & + \\
\hline E. coli ATCC 11775 & - & - & - & - & - & + \\
\hline E. coli ATCC 25922 & - & - & - & - & - & + \\
\hline E. coli(I1) & - & - & - & - & - & + \\
\hline E. coli(I2) & - & - & - & - & - & + \\
\hline E. coli(I3) & - & - & - & - & - & + \\
\hline E. coli(I4) & - & - & - & - & - & + \\
\hline E. coli(I5) & - & - & - & - & - & + \\
\hline C. perfringensATCC13124 & - & - & - & - & - & + \\
\hline B. cereusATCC11778 & - & - & - & - & - & + \\
\hline S. sonnei ATCC 9290 & - & - & - & - & - & + \\
\hline
\end{tabular}

nature sample of each categories was included as negative control after carefully tested using the conventional culture method as described above for the target pathogenic bacteria. Additionally, in order to archive the sensitivity and reproducibility of the multiplex PCR assay, the artificially inoculated and noninoculated of these categories food samples that were incubated for 12, 18 and $24 \mathrm{~h}$ in SEB enrichment medium. As can be seen from Table 5 shows that the multiplex PCR assay was able to correctly identify the presence of the five foodborne pathogens at all different inoculated in the lowest concentration of $10 \mathrm{CFU} /$ $\mathrm{mL}$ in each category of the samples after enrichment for 12 hours in SEB medium (Figure 2). Comparatively, our multiplex PCR assay developed was similar or more sensitive with the same the lowest level of $10 \mathrm{CFU} / \mathrm{mL}$ when compared with Kim et al. [26].

Furthermore, in the more recently reported [45] multiplex PCR assays, Lee et al. (2014) reported a multiplex PCR for simultaneous detection of E. coli 0157:H7, B. cereus, V. parahaemolyticus, Salmonella spp. L. monocytogenes, and S. aureus in various Korean ready-to-eat foods. The multiplex PCR assay developed by Lee et al. (2007) also allowed for simultaneous detection at concentrations of $10^{\circ} \mathrm{CFU} / \mathrm{mL}$ of the pathogenic bacteria, after only $24 \mathrm{~h}$ of incubation time. The multiplex PCR assay established in this study could similar the incubation time when compared with Lee et al. (2007). It could also detect the five foodborne pathogens with the lowest level of $10 \mathrm{CFU} / \mathrm{mL}$ after $12 \mathrm{~h}$ of enrichment. Consequently, a 12 -h enrichment period is 
Table 5. Multiplex PCR results of five pathogens from artificially inoculated three food samples matrices

\begin{tabular}{|c|c|c|c|c|c|}
\hline \multirow{2}{*}{ Pathogens } & \multirow{2}{*}{$\begin{array}{l}\text { Incubation } \\
\text { time (h) }\end{array}$} & \multirow{2}{*}{$\mathrm{CFU} / \mathrm{ml}$} & \multicolumn{3}{|c|}{$\begin{array}{l}\text { Multiplex PCR results detection in } \\
\text { food samples }\end{array}$} \\
\hline & & & Vegetables & \begin{tabular}{|l|} 
Seafood \\
products
\end{tabular} & $\begin{array}{l}\text { Raw meat } \\
\text { fork }\end{array}$ \\
\hline \multirow{21}{*}{$\begin{array}{l}\text { E. coli } 0157: \mathrm{H7} \\
(\text { stx })\end{array}$} & \multirow{7}{*}{12} & 0 & - & - & - \\
\hline & & $10^{0}$ & - & - & - \\
\hline & & $10^{1}$ & + & + & + \\
\hline & & $10^{2}$ & + & + & + \\
\hline & & $10^{3}$ & + & + & + \\
\hline & & $10^{4}$ & + & + & + \\
\hline & & $10^{5}$ & + & + & + \\
\hline & \multirow{7}{*}{18} & 0 & - & - & - \\
\hline & & $10^{0}$ & - & - & - \\
\hline & & $10^{1}$ & + & + & + \\
\hline & & $10^{2}$ & + & + & + \\
\hline & & $10^{3}$ & + & + & + \\
\hline & & $10^{4}$ & + & + & + \\
\hline & & $10^{5}$ & + & + & + \\
\hline & \multirow{7}{*}{24} & 0 & - & - & - \\
\hline & & $10^{0}$ & - & - & - \\
\hline & & $10^{1}$ & + & + & + \\
\hline & & $10^{2}$ & + & + & + \\
\hline & & $10^{3}$ & + & + & + \\
\hline & & $10^{4}$ & + & + & + \\
\hline & & $10^{5}$ & + & + & + \\
\hline \multirow{21}{*}{ S. aureus (nuc) } & \multirow{7}{*}{12} & 0 & - & - & - \\
\hline & & $10^{0}$ & - & - & - \\
\hline & & $10^{1}$ & + & + & + \\
\hline & & $10^{2}$ & + & + & + \\
\hline & & $10^{3}$ & + & + & + \\
\hline & & $10^{4}$ & + & + & + \\
\hline & & $10^{5}$ & + & + & + \\
\hline & \multirow{7}{*}{18} & 0 & - & - & - \\
\hline & & $10^{0}$ & - & - & - \\
\hline & & $10^{1}$ & + & + & + \\
\hline & & $10^{2}$ & + & + & + \\
\hline & & $10^{3}$ & + & + & + \\
\hline & & $10^{4}$ & + & + & + \\
\hline & & $10^{5}$ & + & + & + \\
\hline & \multirow{7}{*}{24} & 0 & - & - & - \\
\hline & & $10^{0}$ & - & - & - \\
\hline & & $10^{1}$ & + & + & + \\
\hline & & $10^{2}$ & + & + & + \\
\hline & & $10^{3}$ & + & + & + \\
\hline & & $10^{4}$ & + & + & + \\
\hline & & $10^{5}$ & + & + & + \\
\hline \multirow{21}{*}{$\begin{array}{l}\text { Salmonella spp. } \\
(\text { invA) }\end{array}$} & \multirow{7}{*}{12} & 0 & - & - & - \\
\hline & & $10^{0}$ & - & - & - \\
\hline & & $10^{1}$ & + & + & + \\
\hline & & $10^{2}$ & + & + & + \\
\hline & & $10^{3}$ & + & + & + \\
\hline & & $10^{4}$ & + & + & + \\
\hline & & $10^{5}$ & + & + & + \\
\hline & & 0 & - & - & - \\
\hline & & $10^{0}$ & - & - & - \\
\hline & & $10^{1}$ & + & + & + \\
\hline & & $10^{2}$ & + & + & + \\
\hline & & $10^{3}$ & + & + & + \\
\hline & 18 & $10^{4}$ & + & + & + \\
\hline & & $10^{5}$ & + & + & + \\
\hline & & 0 & - & - & - \\
\hline & & $10^{0}$ & - & - & - \\
\hline & & $10^{1}$ & + & + & + \\
\hline & & $10^{2}$ & + & + & + \\
\hline & & $10^{3}$ & + & + & + \\
\hline & 24 & $10^{4}$ & + & + & + \\
\hline & & $10^{5}$ & + & + & + \\
\hline
\end{tabular}

\begin{tabular}{|c|c|c|c|c|c|}
\hline & & 0 & - & - & \\
\hline & & $10^{0}$ & - & - & \\
\hline & & $10^{1}$ & + & + & \\
\hline & & $10^{2}$ & + & + & + \\
\hline & & $10^{3}$ & + & + & + \\
\hline & 12 & $10^{4}$ & + & + & + \\
\hline & & $10^{5}$ & + & + & t \\
\hline & & 0 & - & - & \\
\hline & & $10^{\circ}$ & - & - & \\
\hline & & $10^{1}$ & + & + & + \\
\hline & & $10^{2}$ & + & + & + \\
\hline & & $10^{3}$ & + & + & + \\
\hline & 18 & $10^{4}$ & + & + & \\
\hline & & $10^{5}$ & + & + & + \\
\hline L. & & 0 & - & - & \\
\hline L. & & $10^{0}$ & - & - & - \\
\hline monocytogenes & & $10^{1}$ & + & + & + \\
\hline & & $10^{2}$ & + & + & \\
\hline & & $10^{3}$ & + & + & + \\
\hline & 24 & $10^{4}$ & + & + & + \\
\hline & & $10^{5}$ & + & + & \\
\hline & & 0 & - & - & \\
\hline & & $10^{\circ}$ & - & - & \\
\hline & & $10^{1}$ & + & + & \\
\hline & & $10^{2}$ & + & + & \\
\hline & & $10^{3}$ & + & + & + \\
\hline & 12 & $10^{4}$ & + & + & \\
\hline & & $10^{5}$ & + & + & \\
\hline & & 0 & - & - & \\
\hline & & 0 & - & - & \\
\hline & & $10^{0}$ & - & - & \\
\hline & & $10^{1}$ & + & + & \\
\hline & & $10^{2}$ & + & + & \\
\hline & & $10^{3}$ & + & + & \\
\hline & 18 & $10^{4}$ & + & + & \\
\hline & & $10^{5}$ & + & + & \\
\hline V. cholera & & 0 & - & - & \\
\hline$(c t x A)$ & & $10^{0}$ & - & - & \\
\hline & & $10^{1}$ & + & + & \\
\hline & & $10^{2}$ & + & + & \\
\hline & & $10^{3}$ & + & + & \\
\hline & 24 & $10^{4}$ & + & + & \\
\hline & & $10^{5}$ & + & + & + \\
\hline
\end{tabular}

required in this multiplex PCR assay for detecting food samples contaminated with a low level of foodborne pathogens.

For the final analysis of multiplex PCR assay, we chose five of the representative bacteriaus ually associated with foodborne illnesses: E. coli 0157:H7, S. aureus, Salmonella spp, L. monocytogenes and $V$. cholera. The multiplex PCR method is capable of detecting these five pathogens in approximately 16 $\mathrm{hr}$ (12 hr for enrichment, $1 \mathrm{hr}$ for DNA extraction, $2 \mathrm{hr}$ for PCR amplification, $45 \mathrm{~min}$ for capillary electrophoretic separation, and $15 \mathrm{~min}$ for interpretation). This is, by far, faster than 4 to 7 days to complete for each pathogen using a conventional detection method, which relies primarily on direct plating methods and biochemical tests.

\section{Conclusion}

In conclusion, the multiplex PCR assay for simultaneous detection of the five foodborne pathogens in food including $E$. coli 0157:H7, S. aureus, Salmonella spp, L. monocytogenes and V. cholera was successfully developed and validated. It was able to 
sufficient in specifically and simultaneously detecting as few as $10 \mathrm{CFU} / \mathrm{mL}$ of the five pathogens in artificially inoculated food samples after enrichment for $12 \mathrm{~h}$. Finally, each 25 -g sample was mixed with $225 \mathrm{~mL}$ of SEB medium and incubated at $37^{\circ} \mathrm{C}$ for 12-h. Then, each $1 \mathrm{~mL}$ of the culture broth was subjected to the multiplex PCR assay as the schematic representation of detection procedure is presented in Figure 3. The assay is reliable, rapid, specific, and robust. Therefore, it can be another tool for the investigation of microbial contamination in raw food and food products, and will also be useful for identifying the sources of food borne out break

\section{Acknowledgment}

This work was supported by the Vietnam Education Foundation for funding (VEF Fellowship to V.V.G.)

\section{Authors' contributions}

Vo Van Giau collected the samples, performed the experiments, analyzed and interpreted the data and wrote the manuscript. The other authors read, reviewed and provided feedback on the final manuscript.

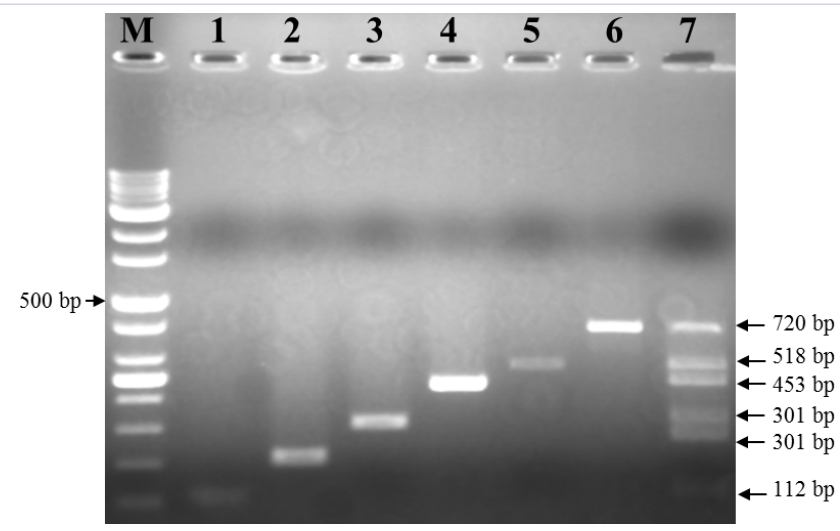

Figure 1: Multiplex PCR reaction applied tosingle and multiple pathogen detection.M, 100-bp DNAladder; lane 1, S. aureusATCC6538; lane 2, Salmonella entericaATCC14028; lane 3, V. choleraATCC17802; lane 4, L. monocytogenesATCC15313; lane 5, E. coli 0157:H7NLU; lane 6, $16 \mathrm{~S}$ rRNA; and lane 7,the five-pathogen mixture.

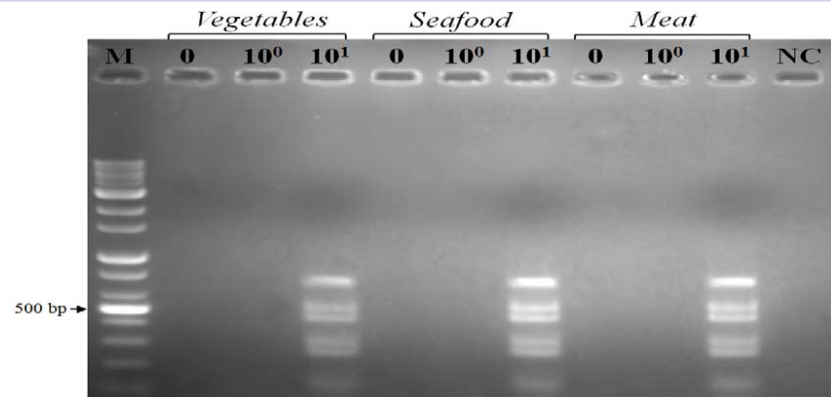

Figure 2: The results of the multiplex PCR assay in three categories of spiked food samples inoculated with different concentrations (showing $0,10^{0}$ and $10^{1}$ colony-forming units $\mathrm{mL}^{-1}$ only) of five pathogens mixture after 12-h enrichment. M, 100 bp DNA ladder; N, negative control

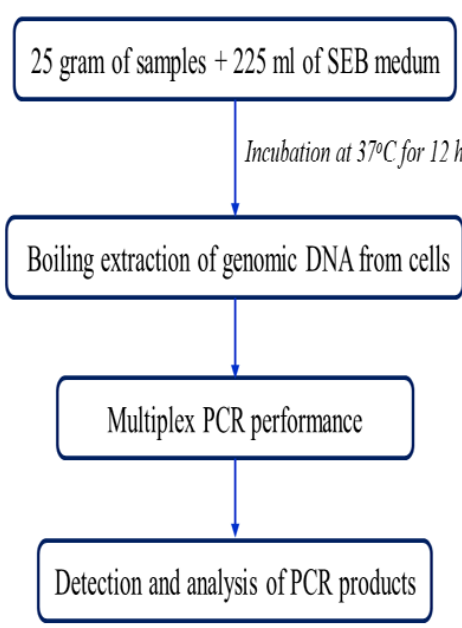

Figure 3: The scheme of multiplex PCR assay for simultaneous detection of E. coli 0157:H7, S. aureus, Salmonella spp., L. monocytogenes and V. cholera.

\section{Conflict of Interest}

On behalf of all authors, the corresponding author states that there is no conflict of interest.

\section{Reference}

1. Chao G, Zhou X, Jiao X, Qian X, Xu L. Prevalence and antimicrobial resistance of foodborne pathogens isolated from food products in China. Foodborne pathogens and disease. (2007);4(3):277-284 doi:10.1089/fpd.2007.0088.

2. Law JW, Ab Mutalib NS, Chan KG, Lee LH. Rapid methods for the detection of foodborne bacterial pathogens: principles, applications, advantages and limitations. Frontiers in microbiology. (2014);5:770. doi.org/10.3389/fmicb.2014.00770.

3. Karmali MA. Infection by Shiga toxin-producing Escherichia coli: an overview. Mol Biotechnol. (2004);26(2):117-22. DOI: 10.1385/ MB:26:2:117.

4. Coffey B, Rivas L, Duffy G, Coffey A, Ross RP, McAuliffe, O. Assessment of Escherichia coli 0157:H7-specific bacteriophages e11/2 and e4/1c in model broth and hide environments. Int J Food Microbiol. (2011):147(3):188-94. doi.org/10.1016/j.ijfoodmicro.2011.04.001.

5. Melton-Celsa A, Mohawk K, Teel L, O’Brien A. Pathogenesis of Shigatoxin producing Escherichia coli. Curr Top Microbiol Immunol. (2012):357:67-103. doi.org/10.1007/82_2011_176.

6. Gobius KS, Higgs GM, Desmarchelier PM. Presence of activatable Shiga toxin genotype $(\operatorname{stx}(2 d))$ in Shiga toxigenic Escherichia coli from livestock sources. J Clin Microbiol. (2003):41(8):3777-83. doi. org/10.1128/JCM.41.8.3777-3783.2003.

7. Baron F, Cochet MF, Pellerin JL, Ben Zakour N, Lebon A, Navarro A, Proudy I, et al. Development of a PCR test to differentiate between Staphylococcus aureus and Staphylococcus intermedius. J Food Prot. 2004;67(10):2302-5.

8. Brakstad OG, Maeland JA. Generation and characterization of monoclonal antibodies against Staphylococcus aureus. APMIS. 1989;97(2):166-74.

9. B M Madison, V S Baselski. Rapid identification of Staphylococcus aureus in blood cultures by thermo nuclease testing. J Clin Microbiol. 1983;18(3): 722-724. 
10. Becker K, von Eiff C, Keller B, Brück M, Etienne J, Peters G. Thermo nuclease gene as a target for specific identification of Staphylococcus intermedius isolates: Use of a PCR-DNA enzyme immunoassay. Diagn Microbiol Infect Dis. 2005;51(4):237-44. doi.org/10.1016/j. diagmicrobio.2004.11.010.

11. Wladimir Padilha da Silva; Jorge Adolfo Silva; Márcia Raquel Pegoraro de Macedo; Márcia Ribeiro de Araújo; Márcia Magalhães Mata, et al. Identification of Staphylococcus aureus, S. intermedius, and S. hyicus by PCR amplification ofcoa and nuc genes. Brazilian Journal of Microbiology. (2003);34:125-127. doi.org/10.1590/S151783822003000500043.

12. Crump JA, Mintz ED. Global trends in typhoid and paratyphoid Fever. Clin Infect Dis. 2010;50(2):241-6. doi: 10.1086/649541.

13. Seonghan Kim, Jonathan G. Frye, Jinxin Hu, Paula J. Fedorka-Cray, Romesh Gautom, David S. Boyle. Multiplex PCR-based method for identification of common clinical serotypes of Salmonella enterica subsp. enterica. J Clin Microbiol. 2006; 44(10): 3608-3615. doi: 10.1128/JCM.00701-06.

14. Galan, JE, Pace J, Hayman MJ. Involvement of the epidermal growth factor receptor in the invasion of cultured mammalian cells by Salmonella typhimurium. Nature. 1992;357:588-589. doi. org/10.1038/357588a0.

15. Galan, J..E., R. Curtiss. Distribution of the invA, -B, -C, and -D genes of Salmonella Typhimurium among other Salmonella serovars: invA mutants of Salmonella Typhi are deficient for entry into mammalian cells. Infection and Immunity.(1991):59:2901-2908.

16. Chen S, Wang F, Beaulieu JC, Stein RE, Ge B. Rapid detection of viable Salmonellae in produce by coupling propidium monoazide with loop-mediated isothermal amplification Appl Environ Microbiol. 2011;77(12):4008-16. doi: 10.1128/AEM.00354-11.

17. Krascsenicsová K, Piknová L, Kaclíková E, Kuchta T. Detection of Salmonella enterica in food using two-step enrichment and real-time polymerase chain reaction. Lett Appl Microbiol. 2008;46(4):483-7. doi: 10.1111/j.1472-765X.2008.02342.x.

18. Wang L, Shi L, Alam MJ, Geng Y, Li L. Specific and rapid detection of foodborne Salmonella by loop-mediated isothermal amplification method.Food Research International. 2008;41(1):69-74. doi. org/10.1016/j.foodres.2007.09.005.

19. Modzelewska-Kapituła M, Maj-Sobotka K. The microbial safety of ready-to-eat raw and cooked sausages in Poland: Listeria monocytogenes and Salmonella spp. occurrence. Food Control. 2014;36(1):212-216. doi.org/10.1016/j.foodcont.2013.08.035.

20. Ryu J, Park SH, Yeom YS, Shrivastav A, Lee SH, Kim YR, et al. Simultaneous detection of Listeria species isolated from meat processed foods using multiplex PCR. Food Control. 2013;32(2):659664. doi.org/10.1016/j.foodcont.2013.01.048.

21. Cabanes D, Dehoux P, Dussurget O, Frangeul L, Cossart P. Surface proteins and the pathogenic potential of Listeria monocytogenes. Trends Microbiol. 2002;10(5):238-45.

22. Farber JM, Peterkin PI. Listeria monocytogenes, a food-borne pathogen. Microbiol Rev. 1991;55(3):476-511.

23. Todd ECD, Notermans S. Surveillance of listeriosis and its causative pathogen, Listeria monocytogens. Food control. 2011;22(9):14841490. doi.org/10.1016/j.foodcont.2010.07.021.

24. Pina M. Fratamico, Arun K. Bhunia, James L. Smith (Eds.). Foodborne Pathogens: Microbiology and Molecular Biology. Emerg Infect Dis. 2006;12(12): 2003. doi: 10.3201/eid1212.061077.
25. Motarjemi Y, Käferstein F. Food safety, Hazard Analysis and Critical Control Point and the increase in foodborne diseases: a paradox? Food Control. 1999;10(4-5):325-333. doi.org/10.1016/S09567135(99)00008-0.

26. Kim JS, Lee GG, Park JS, Jung YH, Kwak HS, Kim SB, et al. A novel multiplex PCR assay for rapid and simultaneous detection of five pathogenic bacteria: Escherichia coli 0157:H7, Salmonella, Staphylococcus aureus, Listeria monocytogenes and Vibrio parahaemolyticus. J Food Prot. 2007;70(7):1656-1662.

27. Mortensen JE, Ventrola C, Hanna S, Walter A. Comparison of timemotion analysis of conventional stool culture and the BD MAXTM Enteric Bacterial Panel (EBP). BMC Clinical Pathology. 2015;15:9. doi. org/10.1186/s12907-015-0010-8.

28. Yamasaki S, Lin Z, Shirai H, Terai A, Oku Y, Ito H, et al. Typing of verotoxins by DNA colony hybridization with poly- and oligonucleotide probes, a bead-enzyme-linked immunosorbent assay, and polymerase chain reaction. Microbiol Immunol. 1996;40(5):345-52.

29. Cabrera-Garcı́a ME, Va'zquez-Salinas C, Quiñones-Ramı́re, EI. Serologic and molecular characterization of Vibrio parahaemolyticus strains isolated from seawater and fish products of the Gulf of Mexico. Appl Environ Microbiol. 2004; 70(11): 6401-6406. doi: 10.1128/ AEM.70.11.6401-6406.2004.

30. Jofre' A, Martin B, Garriga M, Hugas M, Pla M, Rodr'iguezLa'zaro D, et al. Simultaneous detection of Listeria monocytogenes and Salmonella by multiplex PCR in cooked ham. Food Microbiol. 2005;22(1):109115. doi.org/10.1016/j.fm.2004.04.009.

31. Park SH, Kim HJ, Kim JH, Kim TW, Kim HY. Simultaneous detection and identification of Bacillus cereus group bacteria using multiplex PCR. J Microbiol Biotechnol. 2007;17(7):1177- 1182.

32. Ramesh A, Padmapriya BP, Chrashekar A, Varadaraj MC. Application of a convenient DNA extraction method and multiplex PCR for direct detection of Staphylococcus aureus and Yersinia enterocolitica in milk samples. Mol Cell Probes. 2002;16(4):307-314.

33. Sharma VK, Dean-Nystrom EA, Casey TA. Semi automated flurogenic PCR assay (TaqMan) for rapid detection of Escherichia coli 0157:H7 and other Shiga toxigenic E. coli. Mol Cell Probes. 1999;13:291-302.

34. Fratamico PM, Bagi LK, Pepe T. A multiplex PCR for rapid detection and identification of Escherichia coli 0157:H7 in foods and bovine feces. J Food Prot. 2000;63(8):1032-7.

35.Xu YG, Cui LC, Tian CY, Li SL, Cao JJ, Liu ZM, Zhang GC. A multiplex polymerase chain reaction coupled with highperformance liquid chromatography assay for simultaneous detection of six foodborne pathogens. Food Control. (2012);25(2):778-783. doi.org/10.1016/j. foodcont.2011.12.014.

36.Germini A, Masola A, Carnevali P, Marchelli R. Simultaneous detection of Escherichia coli 0157:H7, Salmonella spp., and Listeria monocytogenes by multiplex PCR. Food Control. (2009);20(8):733738. doi.org/10.1016/j.foodcont.2008.09.010.

37. Vo Van Giau, Thuy Trang Nguyen, Thi Kim Oanh Nguyen, Thi Thuy Hang Le, Tien Dung Nguyen. A novel multiplex PCR method for the detection of virulence-associated genes of Escherichia coli 0157:H7 in food. 3 Biotech. (2016);6(1):5. doi: 10.1007/s13205-015-0319-0.

38. Nguyen TT, Van Giau V, Vo TK. Multiplex PCR for simultaneous identification of E. coli 0157:H7, Salmonella spp. and L. monocytogenes in food. 3 Biotech. 2016; 6(2): 205. doi: 10.1007/s13205-016-0523-6.

39. Kobayashi H, Kubota J, Fujihara K, Honjoh K, Ilo M, Fujiki N, et al. 
Simultaneous enrichment of Salmonella spp, Escherichia coli 0157:H7, Vibrio parahaemolyticus, Staphylococcus aureus, Bacillus cereus and Listeria monocytogenes by single broth and screening of the pathogens by multiplex real-time PCR. Food Sci Technol Res. 2009;15:427-438. doi.org/10.3136/fstr.15.427.

40. C H Chiu, J T Ou. Rapid Identification of Salmonella Serovars in Feces by Specific Detection of Virulence Genes, invA and spvC, by an Enrichment Broth Culture-Multiplex PCR Combination Assay. J Clin Microbiol. 1996 Oct; 34(10): 2619-2622.

41. Manzano M, Cocolin L, Ferroni P, Cantoni C, Comi G. A simple and fast protocol to detect PCR Listeria monocytogenes from Meat. J Sci Food Agric. 1997;74(1):25-30

42. H Shirai, M Nishibuchi, T Ramamurthy, S K Bhattacharya, S C Pal, Y
Takeda. Polymerase chain reaction for detection of the cholera toxin operon of Vibrio cholera. J. Clin. Microbiol. 1991;29(11):2517-2521.

43. Kalendar R, Lee D, Schulman AH. FastPCR software for PCR primer and probe design and repeat search. Genes Genom Genomics. (2009);3:114.

44. Anonymous. Microbiology of food and animal feeding stuffs-protocol for the validation of alternative methods (EN ISO 16140). European Committee for Standardization, Paris, France(2002).

45. Lee N, Kwon KY, Oh SK, Chang HJ, Chun HS, Choi SW. A multiplex PCR assay for simultaneous detection of Escherichia coli 0157:H7, Bacillus cereus, Vibrio parahaemolyticus, Salmonella spp., Listeria monocytogenes, and Staphylococcus aureus in Korean ready-to-eat food. Foodborne Pathog Dis. 2014;11(7):574-80. doi: 10.1089/ fpd.2013.1638. 